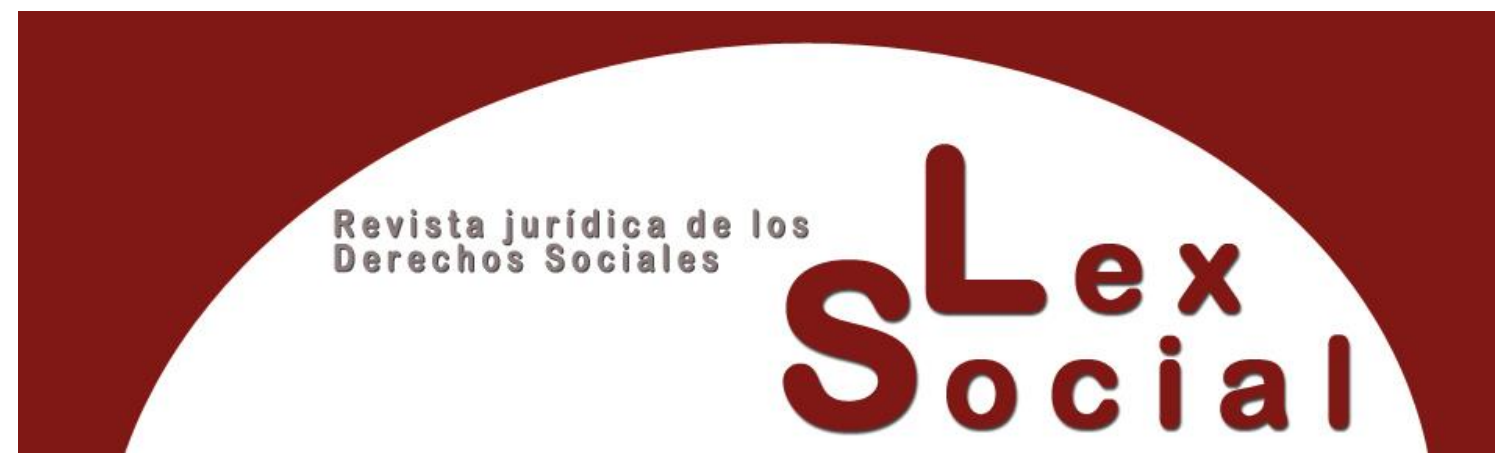

THE NON-DISCRIMINATION PRINCIPLE AND PERSONAL DATA PROTECTION IN THE CONTEXT OF THE EU DIGITAL COVID CERTIFICATE

\title{
EL PRINCIPIO DE NO DISCRIMINACIÓN Y LA PROTECCIÓN DE DATOS PERSONALES EN EL MARCO DEL CERTIFICADO COVID DIGITAL DE LA UE
}

\author{
DIMITRIOS I. KOUKIADIS \\ Adjunct Professor of Law \\ Goethe University Frankfurt/Main \\ https://orcid.org/0000-0002-8873-9437
}

Cómo citar este trabajo: Koukiadis, D. I. (2022). The non-discrimination principle and personal data protection in the context of the EU digital COVID certificate. Lex Social, Revista De Derechos Sociales, 12 (1), pp. 66-88. https://doi.org/10.46661/lexsocial.6452

\begin{abstract}
The measures adopted so far, on EU Members-States level, aiming at containing Covid-19 have, very often, demonstrated an extremely fragmented, un-coordinated and controversial policy-making process. On July $1^{\text {st }}, 2021$, the EU Digital Covid Certificate entered into application throughout the EU seeking to provide for a common, harmonized, common legal framework in order to protect public health, re-open the borders, re-activate European economy, and facilitate the free movement of individuals during pandemic through establishing secure, verifiable, and interoperable measures across the EU territory. Issues of non-discrimination and equality, freedom of movement, working conditions, data protection, asylum and migration, human dignity, the rule of law, and the overall respect for human rights have been raised.
\end{abstract}

\section{(cc) BY-NC-SA}


Regarding the issue of non-discrimination, the Regulation aspires to create a legal framework through which the right to free movement of persons would be facilitated, and the requirements for the gradual lifting of constraints to free movement, imposed by Member States, would be laid down in a coordinated manner.

Considering the personal data protection issues, no derogation from the so far established EU legal framework on personal data protection is foreseen, and all the robust safeguards set by the General Data Protection Regulation (GDPR) on personal data protection are expected to be incorporated in any measure taken by Member States.

KEYWORDS: European constitutionalism; non-discrimination; right to free movement; personal data protection; state of emergency; public interest.

\section{RESUMEN}

Las medidas nacionales adoptadas hasta la fecha, en el seno de la UE, con el fin de contener el Covid-19 han demostrado, muy a menudo, un proceso de elaboración de políticas extremadamente fragmentado, descoordinado y controvertido. El Certificado Digital Covid de la UE entró en vigor en toda la UE el 1 de julio de 2021, el con el fin de proporcionar un marco jurídico común y armonizado para proteger la salud pública, reabrir las fronteras, reactivar la economía europea y facilitar la libre circulación de personas durante la pandemia mediante el establecimiento de medidas seguras, verificables e interoperables en todo el territorio de la UE. Se han planteado cuestiones relativas a la no discriminación y la igualdad, la libertad de circulación, las condiciones de trabajo, la protección de datos, el asilo y la migración, la dignidad humana, el Estado de Derecho y el respeto general de los derechos humanos. En cuanto a la cuestión de la no discriminación, el Reglamento aspira a crear un marco jurídico a través del cual se facilite el derecho a la libre circulación de las personas y se establezcan de forma coordinada los requisitos para la supresión gradual de las restricciones a la misma, impuestas por los Estados miembros. En lo que respecta a la protección de datos personales, no se prevé ninguna excepción al marco jurídico de la UE establecido hasta ahora en esta materia, y se espera que todas las garantías sólidas establecidas por el Reglamento General de Protección de Datos (RGPD) en materia de protección de datos personales se incorporen a cualquier medida adoptada por los Estados miembros.

Palabras Clave: Constitucionalismo europeo; no discriminación; libre circulación; protección de datos personales; estados de excepción; interés público. 


\section{Introduction}

\section{The birth of the European Union Digital Covid Certificate}

III. The Fundamental Rights aspects of the EU digital Covid certificate.

\section{$I V$. The EU digital certificate and the principle of non-discrimination}

V. In lieu of an epilogue

Bibliography

Annex

\section{Introduction}

Since March 2020, when the World Health Organisation (WHO) declared Covid-19 a global pandemic, the pandemic has been setting enormous normative challenges to all levels of constitutionalism applied to the European Union's territory, i.e. national-, supranational-, and international constitutionalism. ${ }^{1}$ The measures so far adopted in the fight against the pandemic have raised an unprecedented collective challenge to the fundamental and human rights of all residents within the EU. ${ }^{2}$ These measures included,

\footnotetext{
*Lecturer of Law, University of Nicosia.

${ }^{1}$ The concept of "multilevel constitutionalism" takes into account all possible versions of "citizenship" an individual can have in a global society. Especially within the EU legal order, an individual is a citizen of her local community, a citizen of her region, a citizen of a Member-State, a citizen of European Union, a citizen of international community, as well as a global citizen. Most of the "citizen" capacities are protected by the relevant levels of constitutionalism, and so are the fundamental rights embedded in each level of constitutionalism. The national Constitutions, the EU primary law (including the EU Charter of Fundamental Rights), the European Convention on Human Rights, the International Covenant on Civil and Political rights offer multiple levels of constitutional protection of fundamental rights of an EU citizen. Moreover, in the era of the $4^{\text {th }}$ Industrial Revolution and digital economy, one more level of "constitutionalism" - transnational constitutionalism - re-appears and aspires to take its place on equal terms with the aforementioned levels of constitutionalism. However, contrary to national, supranational, and international constitutionalism, transnational constitutionalism still remains a controversial, highly disputed, decentralized, fragmented concept. For further analysis on the concept of multilevel constitutionalism, see Ingolf Pernice, "Multilevel constitutionalism and e-democracy", 4 May 2016, available at https://policyreview.info, who analyses the concept of constitutionalism also within the internet ecosystem; see also Ingolf Pernice, "Multilevel Constitutionalism and the Treaty of Amsterdam: European Constitution-Making Revisited?", 36 Common Market Law Review, pp. 703-750 (1999); Martin Loughlin/Petra Dobner (eds.), "The Twilight of Constitutionalism?", Oxford University Press (2010); Gunther Teubner, "Constitutional Fragments: Societal Constitutionalism and Globalization", Oxford University Press (2012); Nicholas Tsagourias (ed.), "Transnational Constitutionalism-International and European Perspectives", Cambridge University Press (2007). In Greek bibliography, see Evangelos Venizelos, "Lectures on Constitutional Law" (in Greek), pp. 10-12, Sakkoulas Athens-Thessaloniki (2021). ${ }^{2}$ The measures taken against Covid-19 pandemic have had, so far, an effect on nearly all other rights protected either by international human rights law, or EU primary law, i.e. the EU Charter of Fundamental Rights (the Charter). Indicatively, regarding the Charter, some of the affected rights have been the rights to liberty and security (Art. 6), private and family life (Art. 7), the protection of personal data (Art. 8), the freedoms of religion (Art. 10), expression and information (Art. 11), assembly and association (Art. 12),
} 
among others, partial or full lockdowns, restrictions on the free movement of individuals, restrictions on private and public gatherings, amendment of the educational process in all levels of education, and various limitations on all scales of economic activity. The above measures, 16 months after the outbreak of the pandemic, are still present in the European as well as the global population having no specific time-frame for the end of their application.

Already experiencing the third wave of the pandemic, a European and global discourse has been launched on the legal reaction to the pandemic and the kind of legal norms that should govern the proposed laws and measures against the pandemic in a EU level as well as worldwide. A constitutional law term often employed to describe and legitimize the measures decided as well as the national laws passed in the fight against Covid-19 has been the "state of emergency" legislation ${ }^{3}$ as opposed to "ordinary legislation".

On a European Union level of policy and law-making, under the principle of subsidiarity, contending such a public health crisis, being an area of the exclusive competence of

the prohibition of discrimination (Art. 21), the freedoms of movement and residence (Art. 45), the right to education (Art. 14), the right to engage in work (Art.15), and the right to healthcare (Art. 35).

For a multi-dimensional overview of the effects of the Covid-19 pandemic on the application of fundamental rights within the EU area, see European Union Agency For Fundamental Rights, "The Coronavirus Pandemic And Fundamental Rights: A Year In Review”, Annual Report 2021, available at https://fra.europa.eu.

${ }^{3} \mathrm{~A}$ number of states have relied on ordinary legislation to manage the pandemic crisis, whereas a number of states resorted to the "state of emergency" powers available in their constitutional law framework. The reasons for resorting to the one or the other form of legislation varies on the legislative standards of each legal order. In some countries, the pandemic crisis did not suffice to constitute a "state of emergency" within their national Constitutional legal order, and the ordinary legislative processes were deemed to be sufficient in order to confront the pandemic.

Due to the fact that a state of emergency can set off a dangerous legal mechanism, which is prone to abuse, it is appropriate not only to precisely determine its elements but also to formalize its inception.

Grogan argues there are four common categories of provisions for a "state of emergency" situation: 1. conditions for its declaration, 2. a delegation of power, 3. limitations on its use; and 4. provisions for legislative or judicial oversight. For a very insightful and comparative overview on the "state of emergency" powers, and the way they were employed during the pandemic period, see Joelle Grogan, "States of Emergency", 26 March 2020, available at https://verfassungsblog.de; See also Steven Bjornskov/Stefan Voigt, "The State of Emergency Virus", 19 April 2020, available at https://verfassungsblog.de.

In the first three months of the pandemic, more than half of the EU's Member States have proclaimed a state of emergency in order to justify the restrictions imposed on some fundamental constitutional rights.. In many EU Member-States' legal and constitutional framework, there are emergency powers to be found. In the Greek Constitution, such powers can be founded on Articles 18 (2), 22(4), 25(4) and 44(1). In France, in March 2020, a new state of a 'health emergency' was declared in order to cope with Covid-19. Article 16 of the French Constitutions provides for the emergency powers of the President. In the German legal order, due to the historic precedents of the Weimar Republic and the following National-Socialist period, the German Constitution (Grundgesetz-GG), in Article 91, foresees a formal proclamation for an external but not for an internal emergency. For further analysis on national approaches to "state of emergency" legislation from a constitutional law perspective, see Evangelos Venizelos, "Pandemic, Fundamental Rights, Democracy" (in Greek), 26 March 2020, available at https://evenizelos.gr; For France's state of emergency reaction to the pandemic, see Sebastien Platon, "From One State of Emergency to Another Emergency Powers in France”, 9 April 2020, available at https://verfassungsblog.de; For an analysis on the German legal order's perception of "state of emergency", see the detailed analysis of András Jakab, "German Constitutional Law and Doctrine on State of Emergency - Paradigms and Dilemmas of a Traditional (Continental) Discourse", 7 German Law Journal, pp. 453-477 (2006). 
Member States, has been primarily the responsibility of EU Member States. ${ }^{4}$ EU institutions, as required by EU primary law may provide coordination and support to the Member-States. However, when the main objective of a proposed action cannot be sufficiently achieved by the Member States, but can rather, by reason of the scale or effects of the proposed action, be better achieved at Union level, the EU institutions may step in. ${ }^{5}$

Besides that, EU primary law applies in case the measures taken by the Member States to contain COVID-19 are closely linked to the implementation of EU law. They may affect non-discrimination and equality in accessing rights, freedom of movement, the internal market, working conditions, data protection, asylum and migration, human dignity, the functioning of democratic institutions, the rule of law, and the overall respect for human rights. In this context, upholding EU primary law when taking decisions to fight the pandemic is obligatory for EU institutions and for Member States when implementing EU law.

The paradigm of the individual Member-States' confrontation of the pandemic has brought forward the inefficiencies of Member-States to stand up against Covid-19 on an individual basis. The scale of the effects caused by Covid-19 on all EU Member-States demonstrated an extremely fragmented, un-coordinated and controversial policy-making. The EU Member-States were in need of a centralized, harmonized, unified policy that would create a common legal framework applied on the whole EU territory. There was a need for an EU legislative initiative in order to protect public health, to re-open the borders, to re-activate European economy, and to facilitate the free movement of individuals during pandemic through establishing secure, verifiable, and interoperable measures across the EU territory.

\section{The birth of the European Union Digital Covid Certificate}

In this context, the European Commission, on March 17, 2021 submitted a proposal for a Regulation $^{6}$ to create a Digital Certificate in order to facilitate a safe, free movement of

\footnotetext{
${ }^{4}$ Article 5(3) of the Treaty on the European Union, which states that "....Under the principle of subsidiarity, in areas which do not fall within its exclusive competence, the Union shall act only if and in so far as the objectives of the proposed action cannot be sufficiently achieved by the Member States, either at central level or at regional and local level, but can rather, by reason of the scale or effects of the proposed action, be better achieved at Union level...", available at https://eur-lex.europa.eu.

${ }^{5}$ Id.

${ }^{6}$ European Commission, "Proposal for a Regulation of the European Parliament and of The Council on a framework for the issuance, verification and acceptance of interoperable certificates on vaccination, testing and recovery to facilitate free movement during the COVID-19 pandemic" (Digital Green Certificate), available at https://eur-lex.europa.eu.

In the general timeline of actions that lead to the above Commission's Proposal, a key actions was also the Council's Recommendation 2020/1475, adopted on 13 October 2020, which launched an EU wide coordinated approach to the restriction of free movement in response to the pandemic in the following key areas: the application of common criteria and thresholds when deciding whether to introduce restrictions to free movement, a mapping of risk areas of Covid-19 transmission, and a coordinated approach to any appropriate measures which could be applied to persons travelling to or from risk areas, depending on the
} 
individuals inside the European Union (henceforth EU) during the COVID-19 pandemic through the establishment of an harmonized legal framework for a common EU certificate.

Throughout the pandemic, all the Member-States of the EU have been experiencing an unprecedented volume of restrictions and prohibitions. These restrictions on communication, free movement, and economic activity have resulted in a very high personal and professional cost for individuals, communities and businesses. After 16 months of fighting the pandemic on the scientific and medical level, a new entry was needed across the EU area to lift the restrictions while protecting public health, to allow the individuals to move freely again, and the EU internal market as well as the national markets to re-open and be re-activated. ${ }^{7}$ The goal was the return of social and economic activity back to normality.

Therefore, the key objective behind Commission's legislative initiative was for the EU to provide for an EU-wide pandemic management to ensure that the EU citizens would benefit from a common digital instrument supporting the re-ignition of European and national economy, and the free movement of EU citizens - with the minimum restrictions - within the EU during the pandemic. The digital certificate was planned to provide for a non-discriminatory tool fully respecting privacy and personal data.

In a record time of less than three months, the final agreement was reached on the Regulation, on May 20, 2021 between the European Parliament and the Council, and, finally, on July $1^{\text {st }}$, the EU Digital Covid Certificate entered into application throughout the EU. The Regulation 2021/953 ${ }^{8}$ (henceforth Regulation) has become official EU law aspiring to fulfill the above mentioned goals and objectives of the European Union.

The Regulation establishes a EU digital certificate (henceforth digital certificate), which is a digital or printed proof that a person has either been vaccinated against Covid-19, or has received a negative PCR of rapid test result, or has already recovered from Covid-19. The digital certificate can be either in digital or paper format, has a QR (Quick Response) code, is free of charge, and is scheduled to be valid across all the EU Member-States.

The Regulation provides all digital certificate holders with a common tool that facilitates the free and safe movement within the EU territory. The question raised is whether the new Regulation provides for the re-starting of EU economy and free movement of individuals in a way that poses or does not pose a threat to core EU

level of risk of Covid-19 transmission in those areas. See Council Recommendation (EU) 2020/1475 of 13 October 2020 on a coordinated approach to the restriction of free movement in response to the COVID-19 pandemic, available at https://www.consilium.europa.eu.

${ }^{7}$ See European Commission, "EU Digital COVID Certificate: EU Gateway goes live with seven countries one month ahead of deadline”, 1 June 2021, available at https://ec.europa.eu.

${ }^{8}$ Regulation (EU) 2021/953 of the European Parliament and of the Council of 14 June 2021 on a framework for the issuance, verification and acceptance of interoperable COVID-19 vaccination, test and recovery certificates (EU Digital COVID Certificate) to facilitate free movement during the COVID-19 pandemic, available at https://eur-lex.europa.eu. 
law's overarching principles and values, such as non-discrimination, privacy, data protection, inclusiveness, and proportionality. Before we go into a more specific analysis on the non-discrimination and personal data issues, let us have a brief overview of the connection between the digital certificate and these issues.

\section{The Fundamental Rights aspects of the EU digital Covid certificate.}

Regarding the discriminatory or non-discriminatory effect of the Regulation, the Regulation creates a legal framework for the issuance of the EU digital certificate aiming at facilitating the individuals bearing this certificate to exercise more easily their right to free movement. It also lays down the requirements under which the gradual lifting of constraints to free movement, imposed by Member States, would take place in a coordinated manner.

The Regulation undoubtedly affects the fundamental right of freedom of movement and residence established in Articles 21 and 45 of the Treaty on the Functioning of the European Union (TFEU) ${ }^{9}$, Article 45 of the EU Charter of Fundamental Rights ${ }^{10}$, and Directive 2004/38 on the right of citizens of the Union and their family members to move and reside freely within the territory of the Member States. ${ }^{11}$ It does so by asking from individuals to hold the digital certificate in order for their movement across the EU to be facilitated. Whenever a Member-State waives certain restrictions on the free movement for individuals being in the possession of the digital certificate, the Regulation allows these individuals to profit from these exemptions. However, the Regulation is not to be interpreted as promoting the adoption of constraints on the free movement of individuals during the pandemic. On the contrary, it aims at providing a common and harmonised framework for the recognition of the various forms of the digital certificate in case a Member State imposes such restrictions.

Any kind of limitations put to the freedom of movement within the EU justified on grounds of public policy, or public health must be necessary, proportionate and based on objective and non-discriminatory criteria. The issue whether to introduce restrictions on

\footnotetext{
${ }^{9}$ Article 21 TFEU: 1. Every citizen of the Union shall have the right to move and reside freely within the territory of the Member States, subject to the limitations and conditions laid down in the Treaties and by the measures adopted to give them effect...", available at https://eur-lex.europa.eu.

Article 45 TFEU: 1. Freedom of movement for workers shall be secured within the Union....3. It shall entail the right, subject to limitations justified on grounds of public policy, public security or public health...

${ }^{10}$ Article 45 of the Charter: Freedom of movement and of residence: 1. Every citizen of the Union has the right to move and reside freely within the territory of the Member States..., available at https://eurlex.europa.eu.

${ }^{11}$ Directive 2004/38/EC of the European Parliament and of the Council of 29 April 2004 on the right of citizens of the Union and their family members to move and reside freely within the territory of the Member States amending Regulation (EEC) No 1612/68 and repealing Directives 64/221/EEC, 68/360/EEC, 72/194/EEC, 73/148/EEC, 75/34/EEC, 75/35/EEC, 90/364/EEC, 90/365/EEC and 93/96/EEC, available at https://eur-lex.europa.eu. A reference to the Directive is to be found in recital 1 of the Regulation 2021/953.
} 
the free movement of individuals, during the pandemic, remains at the discretion of Member States, which must act in compliance with the existing EU legal framework. In the same spirit, a Member State maintains the flexibility not to introduce restrictions to the right of free movement.

Considering the privacy and personal data protection issues, the Regulation encompasses processing of personal data and, specially, health data. Therefore, Article 7 of the EU Charter of Fundamental Rights (the Charter) on the respect of private life, ${ }^{12}$ as well as Article 8 of the Charter on the right to the protection of personal data, ${ }^{13}$ and Article 16 of the Treaty on the Functioning of the European Union (TFEU) on personal data protection ${ }^{14}$ have been all part of the legal reasoning of the Regulation. Most forms of processing the personal data of individuals, i.e. collecting, organizing, structuring, storing, and disclosing personal data affect the right to privacy and the right to protection of personal data under the TFEU and the Charter. Thus, any kind of Interference with these fundamental rights must be justified.

The General Data Protection Regulation (GDPR) ${ }^{15}$ is also very strongly embedded in the text and spirit of the new Regulation. No derogation from the established EU legal framework on personal data protection ${ }^{16}$ is foreseen, and all the robust safeguards set by the GDPR on personal data protection must be incorporated in any measure taken by Member States. The Regulation establishing the new digital certificate is not planned to create a centralized European database on vaccination, testing or recovery from COVID19. The processing of personal data, under the Regulation, is restricted only to the necessary information needed for the identification of the Certificate holder, and for preventing a case of Certificate's falsification or tampering.

\section{The EU digital certificate and the principle of non-discrimination}

Within the EU legal order, any EU legislation can only be applied, when the fundamental rights and the overarching principles of EU law are fully respected and protected.

\footnotetext{
${ }^{12}$ Article 7 of the Charter: Respect for private and family life: Everyone has the right to respect for his or her private and family life, home and communications..., available at at https://eur-lex.europa.eu.

${ }^{13}$ Article 8 of the Charter: Protection of personal data: 1. Everyone has the right to the protection of personal data concerning him or her..., available at https://eur-lex.europa.eu.

${ }^{14}$ Article 16 TFEU: 1. Everyone has the right to the protection of personal data concerning them..., available at https://eur-lex.europa.eu.

${ }^{15}$ Regulation (EU) 2016/679 of the European Parliament and of the Council of 27 April 2016 on the protection of natural persons with regard to the processing of personal data and on the free movement of such data, and repealing Directive 95/46/EC (General Data Protection Regulation), available at https://eurlex.europa.eu.

${ }^{16}$ The EU legal package on personal data protection does not only include the GDPR, but also the Directive (EU) 2016/680 on the protection of natural persons regarding processing of personal data connected with criminal offences or the execution of criminal penalties, and on the free movement of such data, and Regulation 2018/1725 on the processing of personal data by European Union institutions, bodies, offices and agencies. This Regulation is aligned with the General Data Protection Regulation and the Data Protection Law Enforcement Directive.
} 
Considering one of the overarching principles of EU law, i.e. the principle of nondiscrimination, ${ }^{17}$ articles 18 and 19 of TFEU are two of the primary expressions of the objectives of the EU legal system. ${ }^{18}$ According to article 19, the

Council with the European Parliament may take all appropriate actions to combat discrimination based on sex, racial or ethnic origin, religion or belief, disability, age or sexual orientation. Discrimination may be due to either treating people differently on the basis of an irrelevant distinction, or treating in the same way people who are different in relevant ways.

In the same spirit, under article 14 of the European Convention on Human Rights (ECHR) of the Council of Europe any legislation should refrain from discriminating against individuals or groups and should guarantee equal and effective protection against discrimination on any ground, such as race, colour, sex, language, religion, political or other opinion, national or social origin, property, birth or other status. ${ }^{19}$ Moreover, equality before the law means that all individuals are subject to the same laws, with no individual or group having special legal privileges.

Furthermore, under the ECHR, differential treatment may amount to discrimination if it does not have an objective and reasonable justification. That means that a differential treatment can be justified when it a. pursues a legitimate aim, and b. is proportionate.

\footnotetext{
17 Very often the equality principle is understood as the non-discrimination principle. Although the relationship between the two terms is not often made clear, the general principle of equal treatment, as a general principle of Union law, requires that persons in similar situations are not to be treated differently unless that difference in treatment is objectively justified. According to the jurisprudence of the European Court of Justice, the prohibition of discrimination is simply "... a specific enunciation of the general principle equality which is one of the fundamental principles of Union law..." See joined Cases 117/76 and 16/77, Albert Ruckdeschel \& Co. and Hansa-Lagerhaus Ströh \& Co. v Hauptzollamt Hamburg-St. Annen and Diamalt AG v Hauptzollamt Itzehoe., Judgment of the Court of 19 October 1977, par. 7; See also C-127/07, Société Arcelor Atlantique et Lorraine and Others v. Premier ministre, Ministre de l'Écologie et du Développement durable and Ministre de l'Économie, des Finances et de l'Industrie, Judgment of the Court (Grand Chamber) of 16 December 2008, par. 23-25, 46-47. All three judgments available at https://eur-lex.europa.eu.

${ }^{18}$ Article 18 TFEU: "Within the scope of application of the Treaties, and without prejudice to any special provisions contained therein, any discrimination on grounds of nationality shall be prohibited.

The European Parliament and the Council, acting in accordance with the ordinary legislative procedure, may adopt rules designed to prohibit such discrimination.

Article 19 TFEU: 1. Without prejudice to the other provisions of the Treaties and within the limits of the powers conferred by them upon the Union, the Council, acting unanimously in accordance with a special legislative procedure and after obtaining the consent of the European Parliament, may take appropriate action to combat discrimination based on sex, racial or ethnic origin, religion or belief, disability, age or sexual orientation..." available at https://eur-lex.europa.eu.

${ }^{19}$ Article 14 ECHR: Prohibition of discrimination: The enjoyment of the rights and freedoms set forth in this Convention shall be secured without discrimination on any ground such as sex, race, colour, language, religion, political or other opinion, national or social origin, association with a national minority, property, birth or other status, available at https://www.echr.coe.int.
} 
Proportionality demands a fair balance between protecting the interests of the community (the legitimate aim) and respect for the rights and freedoms of the individual. ${ }^{20}$

In the context of the recently established digital certificate, a key allegation is that it is discriminatory to lift restrictions for those who have been vaccinated whilst maintaining them for those who have not. The allegedly discriminatory effect of the digital certificate is based on the premise that from the moment this certificate is available to those who have been vaccinated, differential treatment has already taken place. ${ }^{21}$ In addition to that, in many EU countries vaccines have not been made available to everyone without distinction. On the contrary, the most medically vulnerable groups have been given priority for vaccination. On the top of that, discrimination is also born from the fact that too many vaccination centres, all over the EU, being too distant or inaccessible for specific vulnerable groups, prevent these groups of people from being vaccinated. ${ }^{22}$

Some specific Member-States have managed to vaccinate a higher percentage of their citizens than others. ${ }^{23}$ That could suffice to a discrimination based on nationality, due to the fact that some Member states are progressing faster with vaccination than others. ${ }^{24}$ Likewise, when vaccines would become widely available, vaccination certificates would continue to discriminate based on age, gender and vulnerability, as certain categories of individuals could still not get vaccinated. ${ }^{25}$

Further criticism on the discriminatory effects of the digital certificate is based on the violation of the principle of proportionality. The criticism claims that the goals of confronting the pandemic and lifting the restrictions on the free movement of individuals could be achieved through measures with a lesser impact on fundamental human rights, and, thus, the digital certificate could set a dangerous precedent, allowing for discrimination and enhancing already existing inequalities and disparities. ${ }^{26}$ The bottom line of this argument is that restrictions on the right to the freedom of movement can only take place when they are proportionate, i.e. they are

\footnotetext{
20 See Damien Cottier, "Covid passes or certificates: protection of fundamental rights and legal implications", Coucil of Europe- Committee on Legal Affairs and Human Rights, 17 May 2021, p.8, available at http://assembly.coe.int.

${ }^{21}$ Iris Goldner Lang, "Should the EU Have a 'Digital Green Pass', 'Vaccination Certificate' or Better Nothing?, 16 March 2021, p.2, available at https://verfassungsblog.de.

${ }^{22} \mathrm{Id}$.

${ }^{23} \mathrm{Id}$.

${ }^{24}$ Id., at 3

${ }^{25} \mathrm{Id}$.

${ }^{26}$ Evelyn Paris, "Applying the Proportionality Principle to COVID-19 Certificates", European Journal of Risk Regulation, pp. 1-11, at 6 ff. (2021).
} 
necessary, suitable, and proportionate stricto sensu, ${ }^{27}$ and that they categorically serve the objective of protecting public health. Even in the case, in which all three certificate alternatives are offered - vaccination, negative test, recovery - the non-vaccinated individuals would not be treated equally, as they would have to get a negative PCR test or a proof of recovery, whereas the vaccinated individuals would not have to do that. Thus, until vaccines become widely available across the EU, the digital certificate should not be used, in order to avoid creating a dividing line between the vaccinated individuals and all those who would like to get vaccinated but have not yet managed to do so.

The plausibility of the above allegations notwithstanding, the employment of the "discrimination" argument against the digital certificate does not have a strong factual and legal basis, because it fails to take into account some facts and normative standards, which have been considered in order for the Regulation 2021/953 to be passed, and for the digital certificate to be established. Firstly, at the time the Regulation was put in force, July 2021, all forms of vaccines had been widely available to all EU residents without any differentiation based on gender, age, sex or nationality. At the time this paper is written, the availability of the vaccines has been so broadened that everyone within the EU territory wishing to be vaccinated can be vaccinated.

Secondly, the Regulation makes clear in all its parts - Title, Recitals, and Articles - that its goal is to facilitate the free movement during the COVID-19 pandemic. ${ }^{28}$ The European Commission's key motivation to propose the establishment of a EU wide digital certificate was not to set further restrictions on the right to free movement, and to discriminate the EU citizens between the vaccinated ones and the non-vaccinated ones. The key motivation was to gradually lift the already existing restrictions on free movement in a coordinated manner, and to facilitate, as much as possible, the exercise of the right to move and reside freely within the territory of the Member States. The available tool to accomplish this goal was the adoption of a common framework for the issuance, verification and acceptance of interoperable COVID-19 vaccination, test and recovery certificates. ${ }^{29}$ Not to mention that in all steps of the legislative process, all the available scientific facts, as well as the epidemiological standards have been, throughout time, the principal guides of the legislative process.

Secondly, the pro-discrimination argumentation against the digital certificate is founded on the false premise that the digital certificate divides the EU residents in the vaccinated

\footnotetext{
${ }^{27}$ Walter Van Gerven, "The effect of proportionality on the actions of Member States of the European community: national viewpoints from Continental Europe", in Evelyn Ellis (ed.), The Principle of Proportionality in the Laws of Europe, Hart Publishing (1999).

${ }^{28}$ See Regulation 2021/953, supra note 8 .

${ }^{29}$ Id., recital 12: To facilitate the exercise of the right to move and reside freely within the territory of the Member States, a common framework for the issuance, verification and acceptance of interoperable COVID-19 vaccination, test and recovery certificates...should be established. That common framework should be binding and directly applicable in all Member States. It should facilitate...the gradual lifting of restrictions in a coordinated manner by Member States....
} 
ones and the non-vaccinated ones, the former being the privileged ones whereas the latter being the unprivileged ones. That is not correct. The digital certificate is addressed not only to the ones holding a vaccination certificate, but also to the holders of a certificate confirming that they have been subject to a negative PCR or rapid test, and to the holders of a certificate confirming that they have recovered from a SARS-CoV-2 infection. ${ }^{30}$ Therefore, it is not only the vaccination certificate that will allow individuals to move without restrictions within the EU territory, but also the negative test certificate and the recovery certificate. Following the scientific evidence and the ongoing epidemiological standards, the EU legislators have broadened as much as possible the spectrum of the addressees of the benefits of the right to move from one Member-State to another without restrictions.

Moreover, no single individual EU or non EU, residing legally in a Member-State, is prohibited to move from one country to the other if he/she does not hold one of the above certificates. His/her right to free movement within the EU remains unaffected. Holding or not holding one of the above certificates affects only the facilitation of the free movement ${ }^{31}$ and not the permission of it. The ones who do not wish to get one of the above certificates will still be able to freely travel all over the EU having only the obligation to comply with the health protection protocols of the country of their destination, i.e. covid -19 tests or temporary quarantine. The, so far, one month of digital certificate's operation proves that the digital certificate does not divide and does not discriminate among EU residents. Thousands of tourists are travelling across the EU either with or without one of the three digital certificates. The only difference between them is that the "have nots" ones simply have to go through some extra diagnostic tests to check whether they are infected or not, or a short-term quarantine.

Considering the argument connecting the "discriminatory" effect of the digital certificate with the violation of the principle of proportionality, the Regulation establishing the digital certificate clearly declares its intention to facilitate the application of the principles of proportionality and non-discrimination with regard to restrictions to free movement during the COVID-19 pandemic, and not to facilitate the adoption of restrictions to free movement, or restrictions to other fundamental rights, in response to the COVID-19 pandemic. Whether the establishment of the digital certificate is objective and proportionate, must depend on the nature of the right or freedom in question and the severity of the interference. The freedoms and the rights in question in our case are the core EU freedoms of movement and the pursuit of a high level of public health protection.

Under the principle of proportionality, the content and the form of any EU policy or law shall not exceed what is necessary to achieve the objectives of EU Treaties, and any

\footnotetext{
${ }^{30}$ Id., at Article 3.

${ }^{31}$ Id., at Article 11.
} 
decision must favor the least restrictive option. ${ }^{32}$ In other words, "... when there is a choice between several appropriate measures recourse must be had to the least onerous, and the disadvantages caused are not to be disproportionate to the aims pursued...". 33 Therefore, after having considered the available scientific knowledge, scientific expertise, and the current epidemiological standards of Covid-19 all over the EU (the national differentiations notwithstanding), let us ask ourselves whether, in the case of the digital certificate, was there any other least onerous measure to be taken in order to reestablish the free movement of people and protect public health, or whether the disadvantages caused by the digital certificate are disproportionate to the aim pursued.

Hypothetically, even if we considered that the Regulation, through the establishment of the digital certificate, had created a discriminatory treatment of specific groups of people, would this discriminatory treatment violate the principle of proportionality? Before giving an answer, we should first consider whether the same aim, as declared by the Regulation itself, could be achieved through other means involving treatment that would be less differential and discriminatory. This consideration relates also to the degree of effectiveness of the measure underlying the discriminatory treatment, as part of the "balancing" process between achieving the aim that the Regulation pursues and interfering with individual rights.

Under the same hypothesis, would the discriminatory effect of the digital certificate lack "an objective and reasonable justification"? ${ }^{34}$ Again, before giving an answer to this question, let us think first whether there has been a difference in treatment of persons in

\footnotetext{
${ }^{32}$ Article 5(4) TEU: ...4. Under the principle of proportionality, the content and form of Union action shall not exceed what is necessary to achieve the objectives of the Treaties.

The institutions of the Union shall apply the principle of proportionality as laid down in the Protocol on the application of the principles of subsidiarity and proportionality, available at https://eur-lex.europa.eu. ${ }^{33} \mathrm{C}-331 / 88$, The Queen $v$ Minister of Agriculture, Fisheries and Food and Secretary of State for Health, ex parte: Fedesa and others, Judgment of the Court (Fifth Chamber) of 13 November 1990, par. 12-13, available at https://eur-lex.europa.eu.

Regarding the initial origins of the principle of proportionality, within the realm of Continental European law, its first formulation is traced back in 1794, in Prussia, in the work "Allgemeines Landrecht für die preußischen Staaten", which was the Prussian administrative law for the administration of penalties and police actions. The principle of proportionality introduced a ban on punitive measures that restricted personal liberties beyond what was deemed strictly necessary to protect public safety. In terms of Continental case law jurisprudence, this principle is to be found in Prussian Supreme Administrative Court, in its 1882 ruling on the Kreuzberg case. On the origins and the general application of the principle of proportionality in the EU legal order, see Gino Saccia, "Proportionality and the Balancing of Rights in the case law of European Courts", 20 Februar 2019, available at https://www.federalismi.it; Evelyn Paris, “Applying the Proportionality Principle to COVID-19 Certificates", European Journal of Risk Regulation, pp. 1-11, at 4 ff. (2021).

${ }^{34}$ On the issue of "objective and reasonable justification" interpreted by ECtHR jurisprudence, see Case Molla Salli v. Greece (Application no. 20452/14), Judgement of 19 December 2018 (Grand Chamber), par. 135, available at https://hudoc.echr.coe.int ; See also Fabris v. France (Application no. 16574/08), Judgment of 7 Februar 2013 (Grand Chamber), par. 56, available at https://www.legislationline.org; D.H. and Others v. the Czech Republic (Application no. 57325/00), Judgment of 13 November 2007 (Grand Chamber), par. 175, available at https://hudoc.echr.coe.int; Hoogendijk v. the Netherlands (Application no. 58641/00), Decision of 6 January 2005 (First Section), available at https://hudoc.echr.coe.int.
} 
analogous or relevantly similar situations, or a failure to treat differently persons in relevantly different situations, and if the answer is an affirmative one, let us ask think whether this different treatment is objectively justified, whether it pursuits a legitimate aim, and whether the means employed are reasonably to the aim pursued.

\section{The EU digital certificate and the personal data protection}

Considering the content and the information the digital certificate is planned to include, whether it be information on vaccination status, test results, or previous infection, the implementation of such a document EU wide, undoubtedly raises significant issues of personal data protection. In any case, it requires the processing of personal data, i.e., collection, access and use of personal data, including health data, which all fall under the scope of Regulation 2018/679 (GDPR) ${ }^{35}$, the Charter, ${ }^{36}$ and the Council of Europe's Convention 108 and $108+{ }^{37}$

According to Article 5 of the Regulation 2021/953, the vaccination certificate ${ }^{38}$ shall $^{2}$ contain the following categories of personal data: $\mathbf{a}$. the identity of the holder, $\mathbf{b}$.

information about the COVID-19 vaccine and the number of doses administered to the holder, and c. certificate metadata, such as the certificate issuer or a unique certificate identifier. It is essential that any interference with personal data must be justified under EU primary and secondary law, and, specially, consisted with the application of GDPR. This would be not only for the sake of legal certainty, but also to avoid that the digital certificate has the effect of directly or indirectly imperiling the fundamental right to the protection of personal data, as established under Article 16 TFEU and Article 8 of the Charter.

The European Data Protection Supervisor (EDPS) and the European Data Protection Board (EDPB) in their joint opinion on Commission's Proposal for a Regulation, ${ }^{39}$ as well as the Council of Europe's Consultative Committee on Convention 108, ${ }^{40}$ have

\footnotetext{
${ }^{35}$ See GDPR, supra note 15.

${ }^{36}$ Charter of Fundamental Rights of the European Union, available at https://eur-lex.europa.eu.

${ }^{37}$ Council of Europe Convention 108 on data protection, January 1981, and Council of Europe Convention $108+$ for the protection of individuals with regard to the processing of personal data, June 2018, both available at www.coe.int/dataprotection.

${ }^{38}$ Regulation 2021/953, supra note 8 . Article 5 of the Regulation refers to the Vaccination certificate, whereas Article 6 refers to the Test certificate, and Article 7 to the certificate of recovery. The categories of personal data included in all three certificates are the same, i.e. name of the holder, information on the vaccine, test, recovery, and certificate metadata.

${ }^{39}$ EDPB-EDPS Joint Opinion 04/2021 on the Proposal for a Regulation of the European Parliament and of the Council on a framework for the issuance, verification and acceptance of interoperable certificates on vaccination, testing and recovery to facilitate free movement during the COVID-19 pandemic (Digital Green Certificate), available at https://edpb.europa.eu. "Digital Green Certificate" was the original name of the certificate, which till the final agreement between the European Parliament and the Council changed to EU digital Covid certificate.

${ }^{40}$ Consultative Committee on Convention 108 - Council of Europe, available at https://www.coe.int
} 
highlighted the areas, in which potential dangers might arise for digital certificate's alignment with the EU and the CoE personal data protection legal framework. Needless to mention at this stage that the Regulation clearly states in its recitals its full compliance with the GDPR, the Charter, and the EDPS and the EDPB's joint opinion. ${ }^{41}$

The most important areas of personal data protection encompassed in Regulation 2021/953 are: ${ }^{42}$

- Clear definition of the purpose(s) of the digital certificate.

- Containment only of the personal data necessary for the purpose of facilitating the exercise of the right to free movement during the Covid-19 pandemic.

- Retainment of personal data for no longer than is necessary for its purpose, and in no case longer than the period for which the certificates may be used to exercise the right to free movement.

- Creation of a legal basis for processing personal data.

- Specification of data controllers, data processors, and persons, authorities, and public and private bodies being allowed to access the data.

- A Data Protection Impact Assessment.

The main goal of personal data protection law is to protect a person's rights to privacy and informational self-determination, as guaranteed by Article 16 of TFEU, Articles 7, 8 and 52 of the Charter, Article 8 of the ECHR, and the provisions of GDPR. The Regulation throughout its whole text - recitals and Articles - sufficiently addresses most of the above critical areas of personal data protection.

Considering the first four of the above mentioned areas, they do cover most of the basic principles related to the processing of personal data, as they are defined in Article 5 of GDPR. ${ }^{43}$ These are purpose limitation, data minimization, storage limitation, integrity and confidentiality. Equivalent provisions taking into account these principles are to be also found in the text of the Regulation.

\footnotetext{
${ }^{41}$ See recitals 48, 62, 64 of Regulation 2021/953, supra note 8.

${ }^{42}$ In the following text, the focus will be on the first four areas of personal data processing as they are embedded in the Regulation, i.e. purpose of personal data processing, data minimization, data storage, and the legal basis for personal data processing. The issue of the identification of data controllers, data processors, as well as the public entities having access to the personal data, is covered in Article 10 (6) (7) (8) of the Regulation. Regarding the need for a Data Protection Impact Assessment, whose lack was pointed out by EDPB and EDPS in their joint opinion on Commission's proposal, there is no specific reference in the text of the Regulation.

${ }^{43}$ Article 5 of GDPR establishing the principles relating to processing of personal data is, perhaps, the most important article of the whole Regulation. It gives the basic guidelines on how to read, understand, and interpret the rest of the GDPR text, as well as on how to examine every case related to personal data violation. The article establishes the following principles: principle of lawfulness, fairness and transparency (5.1.a), the principle of purpose limitation (5.1.b), the principle of data minimization (5.1.c), the principle of accuracy (5.1.d), the principle of storage limitation (5.1.e), the principle of integrity and confidentiality (5.1.f), and, finally, what was the real new entry of GDPR, the principle of accountability (5.2)
} 
First in recital 50, and then in Article 10 of the Regulation, there is a clear statement that “...In line with the principle of data minimisation, COVID-19 certificates should contain only the personal data strictly necessary for the purpose of facilitating the exercise of the right to free movement within the Union during the COVID-19 pandemic..."44, and that "...the personal data contained in the certificates issued pursuant to this Regulation shall be processed only for the purpose of accessing and verifying the information included in the certificate in order to facilitate the exercise of the right of free movement within the Union..."45 The requirement for purpose specification constitutes a material aspect of the principle of purpose limitation. ${ }^{46}$ The purpose of the personal data processing within the digital certificate context is sufficiently precise so that it can be assessed what types of processing will be covered. The purpose is specific, i.e. "accessing and verifying the information" included in the digital certificate, precise, and written in a way that can be understood by the data subjects themselves.

Nevertheless, the clarity and specificity of Article 10 (2) notwithstanding, it remains a critical issue to what extend the above Article also covers the introduction of new purposes that may appear in due time in order for a safer, free movement of individuals to take place. The entry of "new purposes" of the digital certificate is already discussed in many EU Member-States under the context of expanding the use of the digital certificate for "internal" purposes, such as setting it as a requirement to enter theaters, cinemas, cafes, restaurants, churches, shops, or even use it in the employment context.

The EDPB and the EDPS already having expressed their concern on the "multiplicity" of purposes of the digital certificate, other than the facilitation of the free movement between EU Member States, argued that this may lead to unintended consequences and risks to the fundamental rights of EU citizens, and asserted that a "new" purpose should, by no means, legally or factually lead to discrimination based on having or not having the digital certificate. ${ }^{47}$ Therefore, they pointed out that any expansion of the initial purpose of the digital certificate must respect Articles 7 and 8 of the Charter and must be in compliance with the GDPR, i.e. Article 6(4) of GDPR. ${ }^{48}$

However, in the text of the Regulation itself, in recital 49, there is a specific reference on the possibility of Member-States to implement a use of digital certificate for "internal" purposes. ${ }^{49}$ A Member-State could implement a national law through which the adoption of a "digital certificate" system for domestic purposes would be EU law

\footnotetext{
${ }^{44}$ Regulation 2021/953, supra note 8 .

${ }^{45}$ Id.

46 See Lukas Feiler/Nikolaus Forgo/Michaela Weigl, "The EU General Data Protection Regulation (GDPR): A Commentary", p. 74 ff., Globe Law and Business (2018).

${ }^{47}$ See EDPB-EDPS Joint Opinion, supra note 39, p. 8.

${ }^{48}$ Id., at 9.

${ }^{49}$ Regulation 2021/953, supra note 8 .
} 
compliant as long as it will be ensured, for the period of application of the Regulation, that the EU digital certificate could be used within a Member-State, in order to avoid that persons travelling from another Member State and using the EU digital certificate are obliged to obtain an additional national digital certificate.

Regarding the compliance of the digital certificate with the principle of data minimization, as this is defined in Article 5 (1c) of GDPR, the Regulation, besides Recital 50, in Article 10(3) very clearly states that the personal data included in the digital certificate shall be limited to what is strictly necessary. In the language of the EU legislator, is evident that the personal data allowed to be included in the digital certificate should be the minimum amount of personal data that the Member-States authorities would need to have access to, in order to facilitate the free movement from one MemberState to another. That means that the personal data collected for the digital certificate should be absolutely relevant and limited to what is necessary in relation to the purposes for which they are processed, and that any Member-State authority could not process more personal data than needed to provide the elements of the service described in the subject matter of the Regulation.

A critical aspect of "data minimization" considering the application of the digital certificate might be how we decide what is "adeaquate", "relevant" and "limited" personal data. ${ }^{50}$ The answer to this question depends on the specified purpose we have for the collection and use of personal data, and on why we need the specific personal data described in Articles 5, 6 and 7 of the Regulation.

On the top of that, for the processing of special categories of personal data, such as the health data ${ }^{51}$ included in the digital certificate, it is even more important to assure that the Member-States authorities collect and retain only the minimum amount of data needed to serve the specific purposes of the digital certificate. This may need to be considered separately for each individual, or for each group of individuals sharing relevant features or traveling from specific Member-States having relevant epidemiological standards. In particular, depending on a case by case analysis of an individual or his/her country of origin, an alternative may be considered either to rectify incomplete personal data, or object to include specific personal data, or even to require to erase unnecessary data.

In any case, given the fragile and malleable landscape of the pandemic, and the nature of sensitive data included in the digital certificate, Member-States authorities should periodically review the collection of the personal data needed to be included in the digital certificate, and check whether the personal data required are sufficient to properly fulfill

\footnotetext{
50 With the term "adequate" personal data is meant sufficient personal data to to properly fulfill the stated purpose of processing; with the term "relevant" is meant the rational link to that purpose; and with the term "limited" is meant that we do not keep personal data for longer than is needed for the stated purpose.

${ }^{51}$ For further analysis on the health "sensitive" data aspect of the digital certificate, see infra in the text on the legal basis analysis of the digital certificate.
} 
the stated purpose of the digital certificate, have a rational link to the stated purpose, and are not more than needed to serve the stated purpose.

Alongside, and very closely linked with, the "purpose limitation" and "data minimization" principles comes also the "storage limitation" principle. The EDPB and the EDPS, already in their joint opinion on the initial Commission's Proposal ${ }^{52}$, had argued that recital 42 and Article 15 of the Proposal ${ }^{53}$ should be amended in order to rule out any future use of the digital certificate once the pandemic will end, and opposed themselves to the open door left by the Proposal, according to which the Commission could, by a delegated Act, declare a further application of the digital certificate if the WHO would declare a public health emergency of international concern.

In this context, GDPR, in Article 5(1e), states that personal data should be kept in a form which permits identification of data subjects for no longer than is necessary for the purposes for which the personal data are processed. Aspiring to be in full compliance with GDPR, the Regulation, in Article 10 (4) also declares that "...the personal data processed for the purpose of issuing the certificates referred to in Article 3(1), including the issuance of a new certificate, shall not be retained by the issuer longer than is strictly necessary for its purpose and in no case longer than the period for which the certificates may be used to exercise the right to free movement...". 54

Ensuring that there will be no processing of personal data when they will be no longer needed, undoubtedly reduces the risk of violating the GDPR, and minimizes the odds of collecting, storing, and sharing personal data that have become irrelevant, excessive, inaccurate, or out of date. ${ }^{55}$ In the time of the pandemic, the factors of "irrelevancy", "accuracy" and "out of date" are of particular significance, since it is these factors that render the digital certificate its practical validation.

Regarding the above skepticism of EDPB and EDPS on the life-expectancy of the digital certificate, the Regulation, in Article 17, specifically limits the duration of the certification scheme to a maximum of 12 months. However, as provided in Article 16 of

\footnotetext{
52 See EDPB-EDPS Joint Opinion, supra note 39, at 10.

${ }^{53}$ EDPB and EDPS considered fundamental that there is a very strict time-frame for the applicability of the digital certificate. The wanted to rule out any further application of the digital certificate beyond its initial time-framework. With the final text of the Regulation, a specific deadline for the application of all forms of the certificate is given, through Article 17, 30 June 2022. Article 16 only provides for a possible extension of the digital certificate in case of a deterioration of the epidemiological standards.

${ }^{54}$ In addition to that, the Regulation, in recital 52, states that "The retention of personal data obtained from the certificate by the Member State of destination or transit or by the cross-border passenger transport services operators required by national law to implement certain public health measures during the COVID-19 pandemic should be prohibited. This Regulation does not provide a legal basis for setting up or maintaining a centralised database at Union level containing personal data."

${ }^{55}$ For a very concise and accurate analysis of the "storage limitation" principle, and also all other aspects of personal data protecton, see the UK Data Protection Authority, i.e. Information Commissioner's Office (ICO) analysis and explanation of personal data protection., available at https://ico.org.uk.
} 
the Regulation, the Commission, after having submitted, by 31 March 2022, a report to the European Parliament and to the Council on the application of this Regulation assessing the effectiveness of the Regulation on the facilitation of free movement, fundamental rights and non-discrimination, as well as on the protection of personal data during the pandemic, may propose for an extension of the application of the Regulation. The key factors, according to which the European Parliament and the Council will determine the extension or not of the application of the Regulation, will be the, till that time, success or not of the digital certificate to serve its purpose, and the development of the epidemiological situation regarding the pandemic.

Lastly, regarding personal data storage limitation, the Regulation followed EDPB and EDPS remarks on data storage ${ }^{56}$, and included in its text that any retention of personal data obtained from the digital certificate by any Member-States authorities should be prohibited ${ }^{57}$ On the top of that, the Regulation does not provide any legal basis for setting up or maintaining a centralised database at Union level containing personal data. ${ }^{58}$ In short, wherever and whenever the personal data of the digital certificate are expected to be processed, this processing is expected to include ony the verification and authentication process of the certificate itself, in order to be confirmed that the digital certificate presented by a person is an authentic, genuine and not a fake one. The personal data of the subject are not saved and not stored locally or centrally at any airport-, port-, or train station checking point.

If personal data are processed for longer than necessary, then, most likely, data processing will also lack a lawful basis for collecting and retaining personal data. The principle of lawfulness, pursuant to Article 5 (1a) of GDPR, means that personal data may be only processed when there is a legal basis pursuant to Articles 6, 9, or 10 of GDPR ${ }^{59}$ This leads us to the significance of a strong legal basis for the digital certificate, in order to lawfully process the special category of health data. The Regulation, in recital 48 , states that it “...establishes the legal ground for the processing of personal data within the meaning of point (c) of Article 6(1) and point ( $g$ ) of Article 9(2) of Regulation (EU) 2016/679, necessary for the issuance and verification of the interoperable certificates provided for in this Regulation..." ${ }^{60}$ Especially, the application of Article 9 (2g) of GDPR, which deals with the exception to the prohibition of processing special categories of personal data, is of significant importance to the application of the digital certificate.

The processing of sensitive data, i.e. health data in the case of the digital certificate, based on a "substantial public interest", requires that this kind of processing is based either on

\footnotetext{
${ }^{56}$ EDPB-EDPS Joint Opinion, supra note 39, at 14.

${ }^{57}$ Regulation 2021/953, Recital 48 and Article 10 (3), supra note 8.

${ }^{58}$ Id., recital 52.

${ }^{59}$ See Lukas Feiler et al., supra note 46, at 74.

${ }^{60}$ Regulation 2021/953, supra note 8.
} 
EU or Member-State law, and that this law should be proportionate to the aim pursued, respect the essence of the right to personal data protection, and provide for suitable measures to safeguard the fundamental rights and the interests of the data subject. ${ }^{61}$ Contrary to Article 6 (1e) of GDPR, where we only need a "public interest" for the processing of personal data, Article $9(2 \mathrm{~g})$ of GDPR specifically refers to the need of a "substantial public interest" for the processing of sensitive health data.

Resorting to the concept of a "substantial public interest", requires first the balancing test between public interest, in the area of public health, and the risks of the personal data subjects. Recital 46 of GDPR may function as a bridge between the wording of recital 48 of the Regulation and the concept of "substantial public interest": "...The processing of personal data should also be regarded to be lawful where it is necessary to protect an interest which is essential for the life of the data subject or that of another natural person...Some types of processing may serve both important grounds of public interest and the vital interests of the data subject as for instance when processing is necessary for humanitarian purposes, including for monitoring epidemics and their spread...". The case of the digital certificate falls under the above criteria of substantial public interest, since its application is necessary and proportionate for confronting and "monitoring epidemics and their spread".

\section{In lieu of an epilogue}

The goal of the European Union adopting Regulation 2021/953 was simply to lay down a legal framework for the issuance, verification and acceptance of interoperable COVID19 vaccination, test and recovery certificates during the pandemic. The EU digital certificate, established through Regulation 2021/953, is so far the sole legal instrument EU wide ensuring a direct, immediate, harmonized and common implementation of EU law in all Member States. Its normative shortcomings notwithstanding, the digital certificate intends to serve only as a tool to develop a coordinated approach towards the lifting of Covid-19-related restrictions on free movement. The aim is not to discriminate between the "haves" and the "have nots" of the digital certificate, but merely to facilitate the holders' exercise of their right to free movement during the pandemic by ensuring their equal treatment across the EU.

In its effort to serve the above goals, the Regulation provides for the legal basis to lawfully process the personal data necessary to issue such certificates, and to process the information necessary to verify and confirm the authenticity and validity of such certificates in full compliance with EU primary law as well as the General Data Protection

\footnotetext{
${ }^{61}$ See relevantly the Court of Justice of the European Union, Joined Cases C-511/18, C-512/18 and C520/18, La Quadrature du Net et al. v. Premier ministre et al. , Judgment of 6 October 2020 (Grand Chamber), par. 132, available at https://curia.europa.eu.
} 
Regulation. Furthermore, the Regulation mostly achieves a fair balance between the objectives of general interest pursued by the digital certificate and the individual interest in self-determination, as well as the respect for her/his fundamental rights to personal data protection and non-discrimination, and other fundamental freedoms, such as freedom of movement and residence.

On the other hand, the digital certificate was not established to restore, on its own, the full regulatory landscape of the EU free movement of people during the pandemic, to set an EU wide holistic governance framework of the pandemic, to impose compulsory vaccination, and to encourage the adoption of restrictions on free movement within the EU territory violating the principles of proportionality and non-discrimination.

It would be fairer to judge the digital certificate for what it is rather than for what it is not, or for what it could, hypothetically, become in the future.

\section{Bibliography}

BJORNSKOV, Steven and VOIGT, Stefan, "The State of Emergency Virus", 19 April 2020, available at https://verfassungsblog.de.

COTTIER, Damien, "Covid passes or certificates: protection of fundamental rights and legal implications", Coucil of Europe- Committee on Legal Affairs and Human Rights, 17 May 2021, available at http://assembly.coe.int.

FEILER, Lukas, FORGO Nikolaus and WEIGL, Michaela, "The EU General Data Protection Regulation (GDPR): A Commentary", Globe Law and Business, 2018.

GROGAN, Joelle, "States of Emergency", 26 March 2020, available at https://verfassungsblog.de; https://doi.org/10.2139/ssrn.3611057

JAKAB, András, "German Constitutional Law and Doctrine on State of Emergency Paradigms and Dilemmas of a Traditional (Continental) Discourse", 7 German Law Journal, pp. 453-477, 2006. https://doi.org/10.1017/S207183220000479X

LANG, Iris Goldner, "Should the EU Have a 'Digital Green Pass','Vaccination Certificate' or Better Nothing?, 16 March 2021, available at ttps://verfassungsblog.de.

LOUGHLIN, Martin and DOBNER, Petra (eds.), "The Twilight of Constitutionalism?", Oxford University Press, 2010. 
PARIS, Evelyn, "Applying the Proportionality Principle to COVID-19 Certificates", European Journal of Risk Regulation, pp. 1-11, 2021. https://doi.org/10.1017/err.2021.27

PERNICE, Ingolf, "Multilevel constitutionalism and e-democracy", 4 May 2016, available at https://policyreview.info, who analyses the concept of constitutionalism also within the internet ecosystem.

PERNICE, Ingolf, "Multilevel Constitutionalism and the Treaty of Amsterdam: European Constitution-Making Revisited?", 36 Common Market Law Review, pp. 703750 ,

https://doi.org/10.1023/A:1018744426756

1999.

PLATON, Sebastien "From One State of Emergency to Another - Emergency Powers in France", 9 April 2020, available at https://verfassungsblog.de.

SACCIA, Gino "Proportionality and the Balancing of Rights in the case law of European Courts", 20 Februar 2019, available at https://www.federalismi.it.

TEUBNER, Gunther "Constitutional Fragments: Societal Constitutionalism and Globalization", Oxford University 2012. https://doi.org/10.1093/acprof:oso/9780199644674.001.0001

TSAGOURIAS, Nicholas (ed.), "Transnational Constitutionalism-International and European Perspectives", Cambridge University Press, 2007. https://doi.org/10.1017/CBO9780511495076

VAN GERVEN, Walter, "The effect of proportionality on the actions of Member States of the European community: national viewpoints from Continental Europe", in Evelyn Ellis (ed.), "The Principle of Proportionality in the Laws of Europe", Hart Publishing, 1999.

VENIZELOS, Evangelos "Lectures on Constitutional Law" (in Greek), Sakkoulas Athens-Thessaloniki, 2021.

VENIZELOS, Evangelos "Pandemic, Fundamental Rights, Democracy" (in Greek), 26 March 2020, available at https://evenizelos.gr.

\section{Annex}


COUNCIL RECOMMENDATION (EU) 2020/1475 of 13 October 2020 on a coordinated approach to the restriction of free movement in response to the COVID-19 pandemic, available at https://www.consilium.europa.eu.

EDPB-EDPS (European Data Protection Board-European - Data Protection Supervisor), Joint Opinion 04/2021 on the Proposal for a Regulation of the European Parliament and of the Council on a framework for the issuance, verification and acceptance of interoperable certificates on vaccination, testing and recovery to facilitate free movement during the COVID-19 pandemic (Digital Green Certificate), available at https://edpb.europa.eu.

EUROPEAN COMMISSION, "EU Digital COVID Certificate: EU Gateway goes live with seven countries one month ahead of deadline”, 1 June 2021, available at https://ec.europa.eu.

EUROPEAN COMMISSION, "Proposal for a Regulation of the European Parliament and of The Council on a framework for the issuance, verification and acceptance of interoperable certificates on vaccination, testing and recovery to facilitate free movement during the COVID-19 pandemic" (Digital Green Certificate), available at https://eurlex.europa.eu.

EUROPEAN UNION AGENCY FOR FUNDAMENTAL RIGHTS, "The Coronavirus Pandemic And Fundamental Rights: A Year In Review”, Annual Report 2021, available at https://fra.europa.eu. 